Article

\title{
Education for Social Transformation (EST) in the Caribbean: A Postcolonial Perspective
}

\author{
Nigel O.M. Brissett \\ Department of International Development, Community, and Environment, Clark University, \\ Worcester, MA 01610, USA; nbrissett@clarku.edu
}

Received: 21 September 2018; Accepted: 5 November 2018; Published: 12 November 2018

\begin{abstract}
This paper critically examines the possibilities of education for social transformation (EST) in the context of the Caribbean Community (CARICOM). This is a region with a history of colonialism and embodies some of the central dilemmas of globalization, such as inequality and environmental precarity. Thus, conceptually, EST holds great promise for social justice and environmental sustainability. The paper argues, however, that EST can be relevant to the region only if it takes account of the enduring deep-seated legacy of asymmetries of power, exploitation and inequality in the broader society and within the education system resulting from colonialism and now exacerbated by globalization's processes. Using postcolonial theory as the analytical frame, the paper highlights these challenges to EST in the context of the Caribbean and also identifies educational principles for EST to be a catalyst for social transformation in the region.
\end{abstract}

Keywords: education for social transformation; CARICOM; postcolonialism; globalization; social justice education; environmental education

\section{Introduction}

Education for social transformation (EST) is emerging as part of the new global discourse of social change, with education promoted as the panacea for the world's most intractable problems. EST promises to engage with and pursue justice in its multiple forms and integrate a deeper, more consequential concern regarding the limits of our use of the environment. The concept and practice of EST are built aspirationally on challenging structures, and the choices they engender that have marginalized people and societies as well as fuelled unconscionable exploitation of the environment. This paper seeks to critically examine the possibilities of EST in the context of the CARICOM (The Caribbean Community (CARICOM) is a grouping of twenty countries: fifteen Member States and five Associate Members. CARICOM Member States: Least Developing Countries: Antigua \& Barbuda, Belize, Commonwealth of Dominica, Grenada, Republic of Haiti (provisional membership), Montserrat, Federation of St. Kitts \& Nevis, St. Lucia, St. Vincent \& the Grenadines; Middle income countries: Commonwealth of the Bahamas, Barbados, Co-operative Republic of Guyana, Jamaica, Republic of Suriname, Republic of Trinidad \& Tobago), a region with a history of colonialism and current exposure to some of the central dilemmas of globalization such as socio-economic inequality and environmental precarity. Conceptually, EST holds great promise for social justice and environmental sustainability within the Caribbean. Yet EST can only be relevant for the region if it takes account of the enduring deep-seated asymmetries of power, exploitation and inequality that have affected systems of education as well as the broader society. Using postcolonial theory as its analytical frame, the paper highlights challenges to EST in the context of the Caribbean but also develops some principles that can guide policies and practices to extract the best of education for purposes of social transformation. 
The paper draws attention to the legacies of colonialism and how they continue and are exacerbated by current neoliberal globalization forces. While CARICOM, as a collection of independent nations with a common colonial past has made significant strides in addressing some of the worst social, economic and educational conditions, a postcolonial analysis reveals that traces of the colonial experience still remain and continue to shape the condition of the member countries. These traces are evident in the political-economic fragilities of the region (for example, the high rates of debt and struggling economies) and the social challenges brought on by violence and high crime rates. These intersect with the region's vulnerability to environmental disaster that has had harmful effects on post-independence social safety nets in Caribbean societies. Post-colonial education inequities, characterized by limited access and a pedagogy akin to master-slave relationships that are utilitarian and acritical, have also had deleterious consequences on Caribbean societies. In contrast, a postcolonial view of EST promotes a pedagogical approach that deliberately turns a critical focus on structures of power, starting from the classroom and into broader socio-political and economic structures at multiple levels.

The paper is organized as follows: Following this Introduction, Section 2 discusses postcolonial theory broadly but also alludes to its direct relevance to the field of education and to EST. This section also features a discussion of the concept of EST, its social justice and environmental components. Section 3 provides a review of the woeful socio-economic and environmental conditions of much of the Caribbean and how these conditions have been shaped by the region's colonial experiences and current neoliberal and global forces. Section 4 summarizes the connection between the structures and processes of education in the Caribbean currently with the region's colonial antecedents. Section 5 presents guidelines for a vision of education for social transformation that relates specifically to structural and pedagogical change. Section 6 concludes by linking these guidelines for EST to the broader goals of social transformation in the region.

\section{Postcolonial Theory and EST}

Postcolonial theory critically engages with colonial processes. Yet significantly as well, it examines the remnants of those encounters as they relate to material, political and economic phenomena and with the physical and socio-psychological impacts of the experience of colonialism [1-5]. A key aspect of postcolonial studies is that the field, while exposing the exploitative and fundamentally degrading experiences of the colonized, moves away from simplistic analytical binaries. Instead, postcolonial theory reveals a complex set of phenomena that explain colonialism's continuing effects on people, societies and institutions today. As such, postcolonial theory helps to explain how modernity and the structures and processes of globalization have deep roots in colonial processes of exploitation and power imbalances. Concurrently, however, postcolonial theory is not limited to merely recalling and remembering the past, nor does it essentialize colonized populations as simply victims. The agency and ongoing efforts of the colonized to reclaim and reconstruct their identities, cultures, societies and institutions constitute important areas of postcolonial analysis. This partially explains why Lavia [6] (p. 281) can rightly claim that postcolonialism is also 'an aspirational project, intent on pursuing the hopefulness that can be found in the imagination of the Caribbean.'

Applied specifically to the field of education, postcolonial theory is used to interpret education's role in the colonization process and to examine how current educational institutions and the knowledge they produce are functions of past colonial legacies [7]. As Lavia [8] (p. 26) observes, postcolonial theory in its application to education 'provides a set of lenses through which the persistent and insidious legacies of European colonialism can be made visible.' In the Caribbean region postcolonial analysis, through the concepts and practices of education, helps to reinterpret and challenge the historical past and the oppressive present. Again, as Lavia [8] (p. 26) notes, postcolonial theory 'posits a decolonizing discourse about schooling and educational practice, putting on the table a productive, critical and engaged role of educating students and radicalizing teachers' practice' and of connecting the past, present and future as 'a necessary philosophical and methodological endeavour 
of educational practice' (p. 281). These liberatory impulses of postcolonial theory serve as the basis for a critical educational agenda of interpretation that helps to move EST from a set of abstract concepts devoid of place-based relevance to the revelation of historical and current contexts that justifies the insistence on specific values for EST and accordingly helps to frame appropriate response(s) to the question-education for what?

\subsection{Social Justice Education: A Postcolonial Lens}

EST is said to consist of two strands, a social justice agenda and the more recent environmental agenda [9]. The social justice stance for education is much more established and familiar, having had a long association with the conceptualization of the purposes of education. As Blackmore [10] (p. 1001) indicates, 'social justice is about what constitutes "fairness" in a "good" society'. Considered from this perspective the social justice agenda of education highlights the issues of power and politics. As such, its central focus is to analyse the underpinnings of inequality that are rooted in socially constructed traits such as race, gender, class, sexual orientation, differentiated abilities and other sources of discrimination. It thereupon fosters resolutions based on principles of human rights and participatory democracy. These principles underlying the social justice strand of education have attained significant credence through the ideas of scholars and advocates such as Illich, Freire, Giroux and other neo-Marxist and critical theorists (e.g., the Frankfurt school). A unifying theme of their perspectives on EST relates to the possibilities of education as a liberatory force capable of facilitating shifts in power relations and enhancing the inclusion of historically marginalized social groups. In addition, EST is regarded as a form of resistance capable of reducing what Bourdieu and Passeron [11] have referred to as the reproductive tendencies of mainstream education.

\subsection{Environmental Discourse in Education}

The other component of education for social transformation, the environmental strand, is comparatively new and seeks to re-interpret what Maclure [9] refers to as education's more utilitarian purposes. One of the main criticisms of utilitarian education is that it supports a neoliberal economic system characterized among other things by capitalist resource extraction and pollution that have led to disastrous results for historically marginalized peoples, societies and the natural environment. Under the guise of neutrality, utilitarian education generally validates knowledge that aids capitalist expansion and consumption and refuses to address the imbalance between socio-market and ecological needs. It is for these reasons that the environmental component of EST aims 'to generate active support for environmental protection and the attainment of a more sustainable balance between human activity and the natural ecology' [9] (p. 1) by employing critical educational pedagogies.

The environmental discourse of EST consists of several different ideas, concepts and practices. These include environmental education (EE), education for sustainable development (ESD) and education for sustainable living. There are also several global phenomena and initiatives that have shaped the environmental component of EST, including the recently concluded United Nations Decade of Education for Sustainable Development 2005-2014, along with several international environmental conferences [12]. Environmental education (EE) is focused on education in, about and for the environment and is now, more so than in its early years, aimed at taking a critical stance in shaping values and attitudes towards the environment [13]. This critical focus is said to have come about through its increasingly interdisciplinary and transdisciplinary approaches that make explicit linkages between environmental concerns and the socio-economic structures that shape people's engagement with the environment [14].

Bostad and Fisher [15] (p. 74) posit that this current environmental discourse is 'often presented as an advancement of EE'. Others vehemently disagree, noting that ESD takes an instrumental, less critical stance that attempts to balance human instrumental needs and the limits of ecological exploitation. Other critics point out that while attempting this 'balance', ESD does not seek to fundamentally alter the existing structural practices that impact the environment. Manteaw [16] (p. 378) argues that ESD 
'has largely lacked a more focused critical analysis' and Tilbury [17] has questioned ESD's empirical merits. At this juncture, the multiple terms and concepts that seek to marry an environmental discourse with education, whether EE, ESD or education for sustainable living, are often seen as ambiguous 'with multiple interpretations' in the 'analysis and debate among scholars in the field' [18] (p. 2). It is therefore virtually impossible to definitively refer to any one of these concepts as the most legitimate or seminal educational environmental discourse. As Payne [19] (p. 70) admits, there is 'some sort of a merger, or a marriage of academic convenience in the published representation' of the various dominant concepts environmental education. In relation to EST, therefore, it is more useful to highlight and use the ultimate aspiration of transformation as the core idea that unites these various concepts.

\subsection{Transformation: The Link between Social Justice and Environmental Protection}

It is clear then that conceptually there is extensive overlap between the social justice and the environmental components of EST. Methodologically, they are both normatively located within critical analytical interpretations of human social and environmental realities-an approach that interrogates the structures that enable as well as limit social justice and environmental protection. These views on education for social transformation insist that change must take place at multiple levels in order for transformation to occur. Therefore, education must facilitate both structural and individual changes and their relation to each other. Here the notion of transformation is particularly significant and instructive. As the United Nations Research Institute for Social Development (UNRISD) [20] (p. 5) theorizes, 'Transformation requires attacking the root causes that generate and reproduce economic, social, political and environmental problems and inequities, not merely their symptoms'.

This is where education and school systems in particular, become important as potential catalysts of transformation. EST aims to challenge those forms of knowledge that Trainor [21] describes as reproducing social and ecological values that are unsustainable, such as the promotion of unchecked economic growth that drives inequality and squeezes resources from the planet, and western consumerist lifestyles fuelled by selfish individualism. Ultimately, these values shape people's decisions, choices and actions which in turn reinforce larger structures of power at local, national and global levels. As Robinson and Shallcross [22] (p. 75) argue, 'sustainable behaviour will not materialize effectively unless it is supported by community based social structures', for which EST has a central role. EST is seen as the stimulus for thought and behavioural change and therefore must do much of the "heavy lifting" in the transformation process. Robinson and Shallcross [22] (p. 75) do acknowledge, however, that while 'schools may be catalysts of change ... they cannot catalyse without the reinforcement from a wider social base'.

Arguably EST's most important contribution to transformation is its combined philosophical and pedagogical approach which is aimed at reconstituting knowledge and changing people's thinking and behaviour. This implies the necessity of fostering critical engagement with broader structures of power [23]. In Manteaw's view [16] (p. 379) any role for education in socio-ecological change 'should first focus on the mind-set and the institutional and cultural practices that have created our unsustainable present'. In order to facilitate this thinking and behavioural change, Sharma and Menteiro [23] (p. 72) argue for programmatic and pedagogical approaches that develop initial 'awareness which then translates to inner sensitivity which [in turn] facilitates significant personal change'. The importance of personal action to EST is also underscored by Robinson and Shallcross [22] (p. 74) who observe that 'a general emphasis on social action is clearly important' in trying to create a more socially and environmentally just world. Similarly, Misiaszek [24] adopts a critical stance that unites the social and the environmental components of EST and points to the imperative of critical pedagogical approaches. Such educational approaches can reveal how dominant power relations help to 'sustain and even intensify socio-economic oppressions' [24] (p. 280). As Misiaszek further argues, learning environments should be democratic, with both teachers and students working together to develop shared meanings related to social and environmental issues [24]. Springett [13] (p. 105) adds that for education to be an effective transformative agent, there needs to be a 'critical pedagogy that 
empower[s] learners to envision' what Huckle [25] (p. 15) calls 'a moral economy of social justice, citizenship and sustainability'. These critical pedagogical ideas find resonance in a postcolonial critique of development and the environment. For example, Hickling-Hudson [26] (p. 293) links the modern use of the environment to the colonial exploitative process and points to 'a research agenda for postcolonial development that calls for deconstructing modernist assumptions which equate non-sustainable development with progress'.

The core principles and aspirational goals of EST, therefore, are not merely relevant to the CARICOM but are likely to serve as the single best hope for social transformation of these societies that have had a turbulent past and face a precarious present, socially and environmentally, in the era of neoliberal globalization. At this point, a deeper examination of the context of the Caribbean is important. The results of such analysis will help develop a postcolonial interpretation of EST for the region.

\section{The Historical and Socio-Economic Context of the CARICOM}

In significant ways, the CARICOM is a product of modernization and development projects, as well as current neo-liberal globalization processes. This is not to suggest, however, that the Caribbean had no history before the Enlightenment and European expansionism. Historical records show that there were many indigenous cultures that stretched along the Caribbean, from the Tainos in the northern Caribbean, to the Caribs in the south. These societies had their own socio-political, economic and cultural systems that evolved over generations. The current context of the CARICOM is the product of modernization largely because of what befell these cultures as a result of European colonialism and the accompanying "civilizing" mission that destroyed most traces of these societies. As Agozino et al. have observed [27], slavery and genocide are legacies of colonialism and they have been significant in the construction of the contemporary Caribbean in multiple and complex ways. With regard to racial makeup, for example, CARICOM people are mostly of African descent, a result of the enslavement and forced transportation of Africans across the Atlantic to the region. Other racial and ethnic groups are products of indentured servitude. There are also traces of a White European plantation owner class among Caribbean peoples. Caribbean food, culture, official languages and Creole dialects are also functions of these colonial encounters. Political systems in the Caribbean are not uniquely drawn from indigenous societies either; they are versions of systems of the colonizer nations from which they eventually gained independence. Additionally, Caribbean economic systems are largely representative of the dominant Western democratic capitalist models, notwithstanding the socialist experiments of the late 1970s. In light of all these historical influences there are now only limited traces of Caribbean indigenous societies in the region. In these many different ways, the CARICOM is a product of the modernization project and, by extension, globalization. The tendencies and impulses of capitalist exploitation are thus deeply embedded in the fabric of Caribbean social and ecological identities, as are current racial and economic inequities.

The current economic state of the Caribbean is likewise rooted in the simultaneous ravages of colonialism and the more recent effects of neoliberal globalization. As Small Island Developing States (SIDS) they share similar sustainable development challenges, including comparatively small populations and economies, limited resources, susceptibility to environmental disasters, vulnerability to global economic shocks and high dependence on international investment [28]. They are countries that are highly indebted, with debt to GDP ratios well beyond the recommended level of $40 \%$ for developing countries [29]. In 2016, for example, Jamaica and Barbados had debt to GDP ratios of $98 \%$ and $128 \%$ respectively and the regional average was 70.7\% [29]. McLean and Charles' [29] (p. 5) research on indebtedness and its impact on the Caribbean has shown the pernicious effect of debt on countries of the region, especially because at no point during the debt trajectory has there been any economic growth, leading to what they refer to as a 'high-debt, low-growth conundrum'. Structural adjustment programs, which have served as a political-economic disciplinary tool since the 1980s, have also been a common economic feature of Caribbean countries. Such programs have 
served as mechanisms that international development organizations, such as the World Bank and the IMF, along with industrialized countries, have used to impose the current neoliberal agenda in the Caribbean region [30].

Besides these economic woes, the Caribbean is prone to natural disasters. Storms, hurricanes, earthquakes and flooding occur annually with significant costs to the region in terms of reconstruction expenditures and loss of productive revenue. While much of this vulnerability is due to broader occurrences of climate change beyond the full control of member states, some of it is also due to poor environmental management and harmful individual practices [31]. The Caribbean is 'the most tourist-intensive region in the world' [32] (p. 1) and this commodification of its environment, along with limited environmental literacy of its people, makes it vulnerable to overuse in the absence of effective policy at national and regional levels. As a result, with environmental disasters threatening the economic stability of the region, McLean and Charles [29] point out that debt and environmental disasters intersect to present even more development challenges. The oppressive economic conditions and environmental precarity have eroded social safety nets and the benefits of numerous development programs instituted after formal colonialism ended. It is not surprising then that, as a report by the Caribbean Development Bank [33] (p. 15) concludes, while substantial progress was made during the early post-independence period, 'high rates of poverty and inequality remain a pressing development challenge.' As the report [33] (p. 49) notes, 'The level of poverty in the Region is high and may have increased in recent years as a result of the world financial crisis, possibly rolling back some of the gains in the reduction of the level of indigence' made after independence.

The Caribbean's turbulent social history of slavery, the brutal plantation system and the post-independence economic and class-based inequities, as well as contemporary geo-politics, are also linked to current violence, crime and social disorder in the region [27]. A recent IDB Series on Crime and Violence in the Caribbean, a region-wide research project, found that while there are different levels of crime across the Caribbean, overall crime and violence have presented a significant hindrance to development and the social fabric of the region. Jamaica, for instance, is one of the most violent places in the world, with 'homicide rates that are notably higher than both the regional and global averages' [34] (p. ix). In Bahamas, the IDB report [35] finds that 'levels of crime and violence have consistently risen during the past decade ... ; the murder rate in the Bahamas has more than doubled in the last 10 years and is now among the highest in the Caribbean region'. Across the countries studied, the IDB report concludes that rising crime and violence pose a major threat to regional social, political and economic aspirations.

\section{Education and the Legacy of Colonialism}

Education throughout the CARICOM has likewise been deeply affected by past and present socio-economic challenges in the region. Much of the colonial enterprise destroyed indigenous social systems and with them the type of education and learning that supported them. Current systems of education in the Caribbean therefore never developed out of indigenous contexts. Instead, schooling began as a model promulgated by colonial empires, a model that failed to consider local circumstances as a basis upon which to generate knowledge production and transfer [36]. On the contrary, because formal education was established primarily for slave owning Whites who lived in the region but could not afford to travel to Britain to be educated [37], schooling was highly exclusionary, denying access for the enslaved Black population. Not until the period of independence across the region in the 1960s, when newly established representative governments gained political control of their education systems, were there deliberate and concerted efforts to make education truly accessible and universal [36].

Yet even after these countries gained education policy control, the system remained highly elitist, with discrimination and exclusion based on skin shade, social class and economic status replacing outright race-based educational inequity. While the best schooling in the region was of high quality comparable to that which existed in colonizer metropolitan centres, the vestiges of colonialism 
remained embedded in curriculum content and classroom pedagogy system and therefore lacked relevance to regional, national and local realities and needs [27,38]. Structurally, as Jules [39] notes, the education agenda was driven not by internal forces and exigencies but rather by paradigms promoted by multilateral educational and financial institutions that retained dominant postcolonial Western biases. Caribbean education continued to be primarily outward looking and consequently was largely inadequate in coming to terms with the unique human, social, economic and environmental needs of the region [38]. Instead, what emerged was a 'plantation pedagogy' which Bristol [38] (p. 72) characterizes as an 'educational practice [that] is essentially a 'black' practice of whiteness which perpetuates a patriarchal understanding of the transfer of knowledge, development by invitation and an uncritical acceptance of international policies holistically implemented within the local educational arena'. Pedagogically, learning spaces continued to rigidly mirror master-slave relationships that translated into teacher-centred models of learning (Bristol [38] (p. 63). This is a practice which some scholars observe continues to exist today [38,39]). As Freire [40] (p. 102) asserted, 'in such educational practice, the social structures are never discussed as a problem that needs to be revealed.' Similarly, Lavia [6] relates this approach to education as a form of acriticality, or fomentation of a culture of silence.

Caribbean education therefore lacks a consistently deep critical engagement with the region's issues and as a result has been more utilitarian in its ethos and practice than it has been transformational. While Caribbean countries have made significant strides in expanding educational opportunities, especially at the primary and secondary levels where near universal access has been accomplished, education has failed to address 'the root causes that generate and reproduce economic, social, political and environmental problems and inequities' [6]. Encapsulating this problematic, Hickling-Hudson [26] (p. 296) states:

The model inherited from European colonial history is more than dysfunctional for the Caribbean goals of improvement. It continues to cause anguish and contributes to the devastating class tensions across the region. If we cannot reshape the model, there is little possibility of improvement in quality, the range of skills, competencies, values and other attributes.

Some important lessons for education emerge from these Caribbean experiences. First, drawing on a postcolonial interpretation of the context of the region, the basic premises, ideas, prejudices and institutions that historically governed Caribbean colonies remain deeply embedded in current social structures [27]. Second, as the challenges of globalization such as economic fragility, increasing disparities in wealth and the cultural effects of neoliberalism and individualism continue unabated, there is growing acknowledgment of a need to understand not only how these processes are rooted in the historical context of the Caribbean but how they continue to exacerbate some of the region's most significant problems. The core goal of education, therefore, should be to provide Caribbean citizens with knowledge that will enable them to critically reflect on their circumstances and thereby envision alternatives that simultaneously improve personal and collective social well-being and the natural environments upon which they ultimately depend. In essence, the mission and practice of education throughout the CARICOM should explicitly embrace transformative goals and processes.

\section{Guidelines for EST in the Caribbean}

The Caribbean's social and environmental profile renders EST as essential if the countries of the region are to progress towards socially and environmentally just societies. The primary goal of EST is to enable learners, young and adult alike to think critically and to challenge intransigent ideas. In order to achieve this goal, however, EST throughout the CARICOM must begin by fostering deep understanding of the following issues unique to the Caribbean:

- how race and identity shape people's behaviour, their privileges and their disadvantages; 
- how the impulse of exploitation and abuse that characterized plantation life and which were woven into the fabric of all institutions, including education, remain and intersect with existing social, economic and ecological challenges;

- how the history of exploitation of the natural environment has rendered the region prone to continuing environmental despoliation;

- how poverty, inequality and crime are tied to historical patterns of discrimination and are now exacerbated by neoliberal globalization;

- how education was built on the structural violence of discrimination and class reproduction;

- why limited access to quality education and the dominance of 'plantation pedagogy' defy possibilities for critical and context-based learning among most young people in the Caribbean;

- how the problems of education are therefore a reflection of problems of Caribbean societies as a whole; and

- how education, by embracing a stronger transformative ethos, can envision possibilities for economic, political and educational rejuvenation and cooperation.

\subsection{EST for Structural Change}

EST in the CARICOM must address deep structural issues shaped by the region's colonial legacy and by the current impact of globalization. It should provide the philosophical foundations that enable young people to understand the dynamics of political and civic power and how this influences decision-making at local and national levels. In so doing, it should serve as a basis upon which young people can gain the confidence and skills necessary to ultimately create alliances that push back against power structures that have historically marginalized most people in the region. Unfortunately, however, structures of education across the region still do not facilitate equal or equitable access to quality education. In this respect, Hickling-Hudson [26] (pp. 296-297) argues that there are four different domains of literacy that schools ought to inculcate in their future citizens: 'the epistemic domain of academic knowledge, the humanist domain of narratives of culture and gender identity, the technical domain of procedural skills and the public domain of socio-political knowledge.' Up to now, however, the stratifying system of schooling prevents the possibility of equitable access to good quality education across the Caribbean and therefore robs most students of opportunities to develop these competencies. Consequently, there is an urgent need to radically redesign education systems so that 'all institutions offer students dominant, critical and powerful literacies across the four domains' [26] (p. 297).

This is not to say, however, that there have been no efforts to broaden access to education and to introduce reforms in schooling. Indeed, enrolment figures throughout the Caribbean have steadily increased since the independence period. Yet there has never been a unifying alternative philosophy of education guiding such reforms and so rising school enrolments essentially have meant the expansion of a flawed postcolonial educational system [39]. In Jamaica, for example, the Reform of Secondary Education (ROSE) programs (I and II) which set out in the early in the 1990s to improve the quality of teaching and learning and boost rates of access and retention did little more than generate superficial changes that fell far short of intended objectives [41]. More recently, in 2004, following the recommendations of a Task Force on Educational Reform, the government of Jamaica initiated another program of reform which has led to important changes such as the formalization of early childhood education and improvements in the administrative and policy-making processes of the Ministry of Education. Yet overall the main purpose of the reform has been to expand and enhance the efficiency of the established neoliberal orientation of schooling. Apart from the slogan, "Every child must learn", school reform in Jamaica has had no guiding social justice philosophy that might signal a commitment to the idea of education for social transformation [42].

A central focus of EST in the Caribbean should be the creation of a new philosophical framework that deliberately sets out to foster the four domains of literacy suggested by Hickling-Hudson [26]. As Jules argues, 'old paradigms must go'; there needs to be a willingness to 'question and rethink 
the foundations of education'.... [N]othing short of complete reinvention of education is needed.' Rather than continuing the pattern of expanding and responding to the alleged needs of a neoliberal global knowledge economy, which in effect perpetuates the legacy of colonialism, a new paradigm of education for social transformation should be guided by the vision of new generations acquiring the critical skills needed to substantially redress the deep social inequities and environmental precarity of the region. At its core, EST should provide citizens with knowledge that can inform their choices in ways that advance the well-being of society and the natural environment. Such education must include deeper engagements with how the Caribbean's long history of oppression has influenced institutions and policy-making decisions of the state and what type of development should be pursued in the future if social relations in the Caribbean are to be substantially improved. It must enable new generations to question the ongoing thrust of neoliberal capitalist development that pays no heed to ecological limits as exemplified in the Jamaica Development Plan: Vision 2030 [43] and the Trinidad and Tobago: Vision 2030 [44]. EST in the Caribbean must provide the philosophical framework that will encourage and enable young people to identify the fundamental problems of these deeply flawed development policies and plans and to thereupon envision alternatives.

\subsection{EST and Pedagogical Change}

EST in the Caribbean has significant implications for pedagogy. Referring again to Hickling-Hudson's [26] four domains of literacy for citizenship and to the ongoing iteration of plantation pedagogy in school systems, there is much critical pedagogical change that must take place in order to address both social justice and environmental problems of the Caribbean. In this regard, Hickling-Hudson [26] (p. 299) is correct in observing that 'the hallmark of educational quality is that teachers prepare people to appraise their systems of governance, understand the implications of international and global change, address patterns of injustice, hold politicians accountable and experiment with problem-solving, both nationally and in alliance with global civic movements.' Similarly, Mains [45] (p. 320) argues for a critical pedagogical approach in the Caribbean based on 'teaching dialectically' and deliberate examination of 'the ways in which related factors being studied influence each other (e.g., economic changes, political activism, indigenous/nativist movements)'. In this way, pedagogy can 'avoid the reproduction of linear narratives of space, place and identity' [45] (p. 320). In essence young people need to learn to be critically aware of how their circumstances are functions of broader structural and historical phenomena. As Bailey (forthcoming) [46] observes, constructivist approaches of teacher training should challenge colonial-influenced modes of teaching and learning and stimulate critical analysis of the phenomena that shape people's lives. In a similar vein, Bristol [38] (p. 3) argues that 'if teachers are to transcend the limitations of the hegemonic discourses endemic to a culture of colonialism, then they must become self-conscious agents of social transformation by constructing their teaching as subversive activity'. Bristol [38] (p. 153) further argues that for teachers 'teaching must become an instrument of re-acculturation; ... a practice which promotes critical cultural consciousness and intellectual independence of their peers and their students.' Lavia [6] (p. 291) likewise refers to the role of teachers in cultivating critical consciousness, noting that critical educational practice is a postcolonial endeavour that 'requires a pedagogy of hope which draws upon evidence provided from within the contested and mediated bowels of the imagination of the Caribbean' (p. 291).

This postcolonial approach should raise students' critical awareness regarding how various historical and current phenomena have contributed to current conditions of inequality and precarity. This hearkens to Freire's [40] (p. 64) view of problem posing education whereby 'people develop their power to perceive critically the way they exist in the world with which and in which they find themselves; they come to see the world not as a static reality but as a reality in process, in transformation.' The contributions of these scholars on issues of pedagogy serve to question the traditional and colonial-based educational relationships that characterize Caribbean classroom settings $[6,27,41]$. In so 
doing, they are all directly focused on re-centring power, especially in the context of knowledge production and consumption in a post-colonial setting.

\section{Conclusions}

For all those with a stake in the education systems of the CARICOM a central preoccupation should be to seriously reflect on the question-education for what? The postcolonial version of EST that this article envisions for Caribbean education systems is one that spurns the hoary plantation pedagogy that remains dominant in school systems. Instead it should aim to generate a deep understanding of the multiple socio-economic and political problems facing the Caribbean as outcomes of colonialism and modernity and of ongoing processes of neoliberal globalization. At the same time, however, EST should also embody a pedagogy of hope by revealing the historical resilience of a region with a turbulent past - a resilience that can inspire individual and collective action capable of paving the way for the development of socio-economic models that more closely integrate the needs of various peoples and existential ecological concerns and instead encourages a pedagogy that develops young people's 'power to perceive critically the way they exist in the world with which and in which they find themselves' [40] (p. 64). From this perspective, schools should be incubators of positive social relationships and social change. Postcolonial EST, therefore, should be a critical-reflective vocation but also 'an aspirational project, intent on pursuing the hopefulness that can be found in the imagination of the Caribbean' [6] (p. 281).

The discourse of EST should also serve as a spur for future research on emerging regional development initiatives that have implications for education in the CARICOM. For example, in relation to the CARICOM Single Market and Economy (CSME), its "[e]ducation sub-program seeks to articulate and harmonize policies and programs throughout the Community so that the people of the Community can be equipped with the necessary knowledge, skills and attitudes to enjoy a better quality of life, contribute to the development of the Region and to compete in the global environment" [47] (p. 1). These aspirations in large part are supported by the newly developed "CARICOM Human Resource Development (HRD) 2030 Strategy: Unlocking Caribbean Human Potential". In the context of this paper's discussion regarding the importance of EST in the region, an important line of future research should be a close analysis of this current regional education and human resource development strategy. Guided by the principles of EST, such research can serve the cause of meaningful educational reform in the region.

Funding: This research received no external funding.

Conflicts of Interest: The author declares no conflict of interest.

\section{References}

1. Frankenberg, R.; Mani, L. Crosscurrents, crosstalk: Race, 'Postcoloniality' and the politics of location. Cult. Stud. 1993, 7, 292-310. [CrossRef]

2. Gandhi, L. Postcolonial Theory: A Critical Introduction; Columbia University Press: New York, NY, USA, 1998.

3. Loomba, A. Colonialism/Postcolonialism; Routledge: New York, NY, USA, 2007.

4. Andreotti, V. Actionable Postcolonial Theory in Education; Palgrave Macmillan: New York, NY, USA, 2011.

5. Young, R.J. Postcolonialism: An Historical Introduction; Wiley Blackwell: Malden, MA, USA, 2016.

6. Lavia, J. The practice of postcoloniality: A pedagogy of hope. Pedagog. Cult. Soc. 2006, 14, 279-293. [CrossRef]

7. Tiffin, H.M.; Ashcroft, B.; Griffiths, G. The Post-Colonial Studies Reader; Routledge: New York, NY, USA, 1995.

8. Lavia, J. Repositioning pedagogies and postcolonialism: Theories, contradictions and possibilities. Int. J. Incl. Educ. 2007, 11, 283-300. [CrossRef]

9. Maclure, R. Special Issue "Education for Social Transformation: Initiatives and Challenges in the Contexts of Globalization and the Sustainable Development Goals" Call for Papers. 2018. Available online: http:/ /www. mdpi.com/journal/education/special_issues/Sustainable_Development_Goals (accessed on 3 July 2018).

10. Blackmore, J. Social justice in education: A theoretical overview. In Handbook of Educational Theories; Information Age Publishing: Charlotte, NC, USA, 2013. 
11. Bourdieu, P.; Passeron, J.C. Reproduction in Education, Society and Culture; Sage: Thousand Oaks, CA, USA, 2000.

12. Springett, D.; Redclift, M. Sustainable development: History and evolution of the concept. In Routledge International Handbook of Sustainable Development; Redclift, M., Springett, D., Eds.; Routledge: New York, NY, USA, 2015; pp. 3-38.

13. Springett, D. Education for Sustainable Development: Challenges of a critical pedagogy. In Routledge International Handbook of Sustainable Development; Redclift, M., Springett, D., Eds.; Routledge: New York, NY, USA, 2015; pp. 105-120.

14. Kopnina, H. Revisiting education for sustainable development (ESD): Examining anthropocentric bias through the transition of environmental education to ESD. Sustain. Dev. 2014, 22, 73-83. [CrossRef]

15. Bostad, I.; Fisher, A.D. Curriculum and Social Change in Education for a Sustainable Future? In Human Rights in Language and STEM Education; Babaci-Wilhite, Z., Ed.; Sense Publishers: Rotterdam, The Netherlands, 2016; pp. 71-90.

16. Manteaw, O.O. Education for sustainable development in Africa: The search for pedagogical logic. Int. J. Educ. Dev. 2012, 32, 376-383. [CrossRef]

17. Tilbury, D. Education for Sustainable Development: An Expert Review of Processes and Learning; UNESCO: Paris, France, 2011; Available online: http:/ / unesdoc.unesco.org/images/0019/001914/191442e.pdf (accessed on 18 June 2018).

18. Stevenson, R.B.; Brody, M.; Dillon, J.; Wals, A.E. International Handbook of Research on Environmental Education; Routledge: New York, NY, USA, 2013.

19. Payne, P.G. The politics of environmental education. Critical inquiry and education for sustainable development. J. Environ. Educ. 2016, 47, 69-76. [CrossRef]

20. United Nations Research Institute for Social Development. Policy Innovations for Transformative Change: Implementing the 2030 Agenda for Sustainable Development; United Nations (UN), 2017. Available online: http:/ / www.unrisd.org/80256B42004CCC77/(httpInfoFiles)/2D9B6E61A43A7E87C125804F003285F5/ \$file/Flagship2016_FullReport.pdf (accessed on 5 July 2018).

21. Trainer, T. Towards an ecological philosophy of education. Aust. J. Educ. Stud. 1990, 10, 92-117.

22. Robinson, J.; Shallcross, T. Social change and education for sustainable living. Curric. Stud. 1998, 6, 69-84. [CrossRef]

23. Sharma, R.; Monteiro, S. Creating social change: The ultimate goal of education for sustainability. Int. J. Soc. Sci. Humanit. 2016, 6, 72-76. [CrossRef]

24. Misiaszek, G.W. Ecopedagogy and Citizenship in the Age of Globalisation: Connections between environmental and global citizenship education to save the planet. Eur. J. Educ. 2015, 50, 280-292. [CrossRef]

25. Huckle, J. Realizing Sustainability in Changing Times. In Education for Sustainability; Huckle, J., Sterling, S., Sterling, S.R., Eds.; Earthscan: New York, NY, USA, 1996.

26. Hickling-Hudson, A. Towards Caribbean 'knowledge societies': Dismantling neo-colonial barriers in the age of globalisation. Compare 2004, 34, 293-300. [CrossRef]

27. Agozino, B.; Bowling, B.; Ward, E.; St Bernard, G. Guns, crime and social order in the West Indies. Criminol. Crim. Justice 2009, 9, 287-305. [CrossRef]

28. Commonwealth Secretariat. A future for Small States: Overcoming Vulnerability; Commonwealth Secretariat: London, UK, 1997.

29. McLean, S.; Charles, D. Caribbean Development Report: A Perusal of Public Debt in the Caribbean and Its Impact on Economic Growth; United Nations-ECLAC: Santiago, Chile, 2018; Available online: https:/ / www.cepal.org/en/publications/43312-caribbean-development-report-perusal-publicdebt-caribbean-and-its-impact (accessed on 4 July 2018).

30. Henke, H. Jamaica's decision to pursue a neoliberal development strategy: Realignments in the state-business-class triangle. Lat. Am. Perspect. 1999, 26, 7-33. [CrossRef]

31. CARICOM Secretariat. Strategic Plan for the Caribbean Community 2015-2019: Repositioning Caricom. CARICOM: Turkeyen-Guyana, 2014. Available online: https://caricom.org/documents/11265-executive_ plan_vol_1_-_final.pdf (accessed on 1 August 2018).

32. UNESCO. A Caribbean Strategy to Cope with Climate Change. Available online: http://www.unesco. org/new/en/media-services/single-view/news/a_caribbean_strategy_to_cope_with_climate_change/ (accessed on 5 June 2018). 
33. Caribbean Development Bank. The Changing Nature of Poverty and Inequality in the Caribbean: New Issues, New Solutions. St. Michael Barbados. 2016. Available online: http:/ /www.caribank.org/wp-content/uploads/ 2016/05/Study_The-Changing-Nature-of-Poverty-and-Inequality-in-the-Caribbean-New-Issues_-NewSolutions.pdf (accessed on 1 July 2018).

34. Harriot, A.D.; Jones, M. Crime and Violence in Jamaica: IDB Series on Crime and Violence in the Caribbean; Inter-American Development Bank, 2016. Available online: https://publications.iadb.org/handle/11319/ 7773 (accessed on 24 June 2018).

35. Sutton, H. Crime and Violence in The Bahamas: IDB Series on Crime and Violence in the Caribbean; Inter-American Development Bank, 2016. Available online: https://publications.iadb.org/handle/11319/7771 (accessed on 6 July 2018).

36. Edwards, P.A. Education for Development in the Caribbean; Caribbean Ecumenical Consultation for Development: Bridgetown, Barbados, 1971.

37. Bacchus, M.K. Utilization, Misuse, and Development of Human Resources in the Early West Indian Colonies; Wilfrid Laurier University Press: Waterloo, ON, Canada, 1990.

38. Bristol, L.S. Plantation Pedagogy: A Postcolonial and Global Perspective; Global Studies in Education; Peter Lang: New York, NY, USA, 2012; Volume 16.

39. Jules, D. Rethinking education for the Caribbean: A radical approach. Comp. Educ. 2008, 44, $203-214$. [CrossRef]

40. Freire, P. Pedagogy of the Oppressed; Penguin Books: Harmondsworth, UK, 1997.

41. Knight, J.A.; Rapley, J.O. Educational Reform in Jamaica: Recommendations from Ireland, Finland and Singapore; Caribbean Policy Research Institute, 2007. Available online: http:/ / capricaribbean.org/sites/default/files / public/documents/working_paper/education_reform.pdf (accessed on 2 August 2018).

42. Brissett, N.O. A Critical Analysis of Jamaica's Emerging Educational Policy Discourses in the Age of Globalization. Ph.D. Thesis, University of Massachusetts Amherst, Amherst, MA, USA, 2011.

43. Planning Institute of Jamaica. Vision 2030 Jamaica: National Development Plan. 2009. Available online: http:/ / www.vision2030.gov.jm/National-Development-Plan (accessed on 5 August 2018).

44. Ministry of Planning and Development. Vision 2030. Port of Spain, Trinidad and Tobago. 2017. Available online: https: / /www.planning.gov.tt/content/vision-2030 (accessed on 19 July 2018).

45. Mains, S.P. Teaching transnationalism in the Caribbean: Toward an understanding of representation and neo-colonialism in human geography. J. Geogr. High. Educ. 2004, 28, 317-332. [CrossRef]

46. Bailey, E. Resetting the Instructional Culture: Constructivist Pedagogy for Learner Empowerment in the Postcolonial Context of the Caribbean. In Achieving Inclusive Education in the Caribbean and Beyond: From Philosophy to Praxis; Blackman, S.N., Conrad, D.A., Brown, L.I., Eds.; Springer: New York, NY, USA, forthcoming.

47. CARICOM. Education Overview. Available online: https://caricom.org/work-areas/overview/education/ P85 (accessed on 6 August 2018). 